\title{
Survey of the Gatrointestinal Parasites of Pigeon (Columbia Livia Domestica- Gmelin-1789 Aves: Columbidae) from Katsina-Nigeria
}

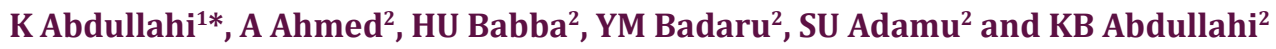 \\ ${ }^{1}$ Department of Biological Sciences, Usmanu Danfodiyo University, Sokoto, Nigeria \\ ${ }^{2}$ Department of Biology, Umaru Musa Yar'adua University, Katsina, Nigeria
}

*Corresponding author: K Abdullahi, Department of Biological Sciences, Usmanu Danfodiyo University, Sokoto, Nigeria, Tel: 24803604 7337; Email: kabdul1@hotmail.com

\begin{abstract}
The domestic pigeon (Columba livia domestica) is the world's oldest domesticated bird and it is important in lives of humans, it provides meat, it is used in research, exhibition, sports and it was once used to deliver messages during wars. The domestic pigeon is however affected by a number of ecto and endoparasites, which of universal occurrence and there is little or no available data about the gastrointestinal parasites of domestic pigeon in Katsina township where it is frequently consumed as a source of protein. This study is therefore a preliminary study of the gastrointestinal parasite of domestic in Katsina metropolis carried out in two study sites namely; abattoir of the central market and chicken slaughtering site, at Yan Turaku. A total of 100 intestinal tract samples were collected between the months of July to December 2017 and examined for gastrointestinal parasites at the Laboratory of the Department of Biology, Umaru Musa Yar'adua University, Katsina, Nigeria. The results of this study showed a total of 23 pigeons were infected representing 23\% (27.1-19.2)95 CI. The results showed that central market abattoir had 14/50 (28.0\%, 29.7-23.3 95\% CI) and 'Yar Turaku had 9/50 (18.0\%, 20.1 -14.5 95\% CI). Three species of parasites were countered in both the study sites, which were, Ascaridia columbae (a nematode), Raillitina species (a cestode), and Capillaria species (also a cestode). The parasite intensity was mild for both the sites and the respective intestinal parasites. The study has revealed the presence of gastrointestinal parasites of domestic pigeon in Katsina Township. The prevalence was however lower compared to other studies and there was no significant difference between the occurrence of the parasites from the two study sites, and there no difference between rates of infection of three parasites encountered as this is may be due the fact the sample size was relatively smaller. Further research is being undertaken to widen the scope of study.
\end{abstract}

Keywords: Gastrointestinal parasites; Prevalence; Intensity

\section{Introduction}

The domestic pigeon (Columba livia domestica Gmelin, 1789) [1] is a pigeon subspecies that was derived from the rock dove (also called the rock pigeon) is the world's oldest domesticated bird [2,3]. The importance of domestic pigeon to the humankind cannot be over emphasized, in war and peace, provides food (meat), it has been used in research, exhibition and sports to mention but a few [4]. In Nigeria domestic pigeon are reared for meat, as pet and used a symbol of peace in National Ceremonies. The domestic pigeon is however affected by a number of ecto and endoparasites, which of universal occurrence. Gastro-intestinal parasites are ubiquitous, especially where climatic and many environmental factors provide near-perfect conditions for their survival and development. Gastrointestinal parasites are common in both temperate and tropical countries, they are more prevalent in most geographical zone of Nigeria where sanitation is poor, and standard of living is low and cause enormous economic losses due to the associated morbidity and mortality [5].

Gastrointestinal tract parasites are known to be wide spread in animals, the direct loses caused by these parasites are attribute to acute illness and death. Premature slaughter and rejection of some parts at meat inspection. Indirect loses include diminution of productive potential such as decrease growth rate, weight loss 
in young growing animal and late maturity of slaughter stock [6]. The effect cause of intestinal parasite on animals is not easily detected by the pastoralist because of the generally sub-clinical chronic nature of the helminthes infection. Thus; the sub- clinical parasitic infection is responsible for significance economic loss, because once clinical disease is noticed in a group of animals much economic loss terms of animal productivity has already occurred [7]. The parasitic gastroenteritis continues to be a major limiting factor to meat production in Nigeria and the helminthes parasite cause a high mortality in pigeon, the parasite reduces the quality of meat affecting human population indirectly, therefore improving the health of pigeon is improving the health of human population [6]. There is general acceptance that infection the health of helminthes coincides with the change of certain climatic condition such as rainfall, relative humidity and high temperature. There is a record of high prevalence of gastro intestinal helminthes parasites during the rainy season, and this season is known to have high temperature and relative humidity [5].

Several health problems can affect pigeon where gastrointestinal parasite infection plays a major role. Among different gastrointestinal helminthes, nematodes are the most deleterious parasites responsible for occurrence of clinical and sub clinical parasitic diseases [8]. Moreover, they are also severely affected by gastrointestinal parasites which are responsible for clinical condition such as anemia, which may ultimately lead to mortality [9-11]. This was a preliminary research study to find the prevalence of the gastrointestinal parasitic infections of domestic pigeon at Katsina Township, Katsina State. This is because there is no available data on the endoparasites of domestic pigeon readily available. The data from this investigation will give an overall idea about the presence or otherwise of gastrointestinal parasitic infections of pigeon in the metropolis. This data may ultimately assist the veterinary clinicians the preliminary data for the forecast and plan on prevention and control measure appropriate for the future. The study is aimed providing the preliminary prevalence and identification of gastro intestinal parasite of pigeons slaughtered in Katsina abattoir, Katsina State-Nigeria.

\section{Materials and Methods}

\section{The Study Area}

The study was carried out Katsina metropolis namely; abattoir of the central market and chicken slaughtering site, Yar' Turaku within Katsina township. Katsina town is capital city of Katsina State was founded in 1987 from the then Kaduna, North Central State, Nigeria. Katsina is also a Local Government Area Council, on geographic coordinates $12^{\circ} 59^{\prime} \mathrm{N} 7^{\circ} 36^{\prime} \mathrm{E}$, and a total land area of about $142 \mathrm{~km}^{2}$ (55 $\mathrm{mi}^{2}$ ) [12]. The population of the metropolis was 459,022 [13]. The most of the inhabitants are Hausa-Fulani and majority are civil servants and traders but the state capital is also a centre of agricultural activities [12,13]. The weather can be classified into two zones in term of climate which are the tropical continental and semi-arid continental. Generally, climate varies considerably according to months and seasons. A cool dry (harmattan) season from December to February; a hot dry season from March to May; a warm wet season from June to September; a less marked season after rains during the months of October to November, characterized by decreasing rainfall and a gradual lowering of temperature [14].

\section{Sample Collection}

The research was approved by the Biology Department of Umaru Musa Yar'adua University, Katsina and permission of relevant Ministry was obtained. A total of 100 intestinal tract samples were collected from Central market abattoir and 'Yan Turaku slaughtering site between the months of July to December 2017. The samples were placed in a clean polythene back and transport in ice packaging to the Laboratory of the Department of Biology, Umaru Musa Yar'adua University, Katsina, Nigeria, for further analysis $[4,5]$. The alimentary tract was separated out and then differentiated into oesophagus, crop, proventriculus, gizard, duodenum, small intestine, caecum and rectum into petridishes containing normal saline solution. These parts of the alimentary tract were cut open with scarpel by logiditunal incision and a binocular dissecting microscope was used to identify the parasites according to similar procedure of Henrin and Robertson 2016, [15]. Helminth parasites extracted were grouped and fixed in Acetic Formal Alcohol (AFA) and for both groups cleared in lactophenol and stained in borax carmine (diluted with lactophenol). Dehydration was done by an upgrading of ethanol. The parasites were identified according to Soulsby [6], Cheng [16] and Ashrafihelan [17].

\section{Statistical Analysis}

The data obtained in the study was recorded into Excel spread for Windows 8.1 sheet. Percentages were obtained and analysis of variance was applied to compare if there were any significant differences between the variables and a $p$ value of $<0.005$ is considered significant.

\section{Result and Discussion}

Table 1: Prevalence of gastrointestinal parasites of pigeon slaughtered in Katsina abattoir, Katsina State.

\begin{tabular}{|c|c|c|c|}
\hline Study site & $\begin{array}{c}\text { No. of pigeons } \\
\text { examined }\end{array}$ & $\begin{array}{c}\text { Number } \\
\text { infected }\end{array}$ & $\begin{array}{c}\text { Prevalence (\%) } \\
\text { 95\% CI }\end{array}$ \\
\hline Central market & 50 & 14 & $28.0(23.3-29.7)^{\mathrm{a}}$ \\
\hline Yar' Turaku & 50 & 9 & $18.0(14.5-20.1)^{\mathrm{a}}$ \\
\hline TOTAL & 100 & 23 & $23.0(19.2-27.1)$ \\
\hline $\mathrm{p}=0.0578$ & & & \\
\hline
\end{tabular}

The superscript letter a indicates insignificant difference of the prevalence between the study sites.

The results of this study showed a total of 23 pigeons were infected representing 23\% (27.1-19.2) 95 CI. The central market abattoir had 14/50 (28.0\%, 29.7-23.3 95\% CI) and 'Yar Turaku had $9 / 50$ (18.0\%, 20.1-14.5 95\% CI) as seen in Table 1. In the central 
market abattoir, three species of parasites were encountered namely, Ascaridia columbae (a nematode), with 16/30, having a prevalence of 53.3\% (48.3 54.7, $95 \mathrm{CI}$ ), Raillitina species (a cestode), was $12 / 30$, with a prevalence of $40(36.6-42.4,95 \% \mathrm{CI})$ and Capillaria species (also a cestode), with $2 / 30$, and a prevalence of 6.7(3.7-7.7), 95\% CI). The parasite intensity ranged from $0.07+0.03$ to $3.8+1.1$, as seen in Table 2. In the Yar Turaku study site, three species of parasites were also encountered as indicated previously namely, Ascaridia columbae (a nematode), with 9/16, having a prevalence of 56.3(50.8, 59.2, $95 \mathrm{CI}$ ), Raillitina species (a cestode), was $4 / 16$, with a prevalence of $25(20.1-29.9,95 \% \mathrm{CI})$ and Capillaria species (also a cestode), with 3/16, and a prevalence of $18.7(13.2-23.3,95 \% \mathrm{CI})$. The parasite intensity was relatively ranged from $0.09+0.1$ to $2.8+0$, as seen in Table 3 .

Table 2: The number of species of intestinal parasite of pigeon encountered at the Central Market.

\begin{tabular}{|c|c|c|c|}
\hline Parasite & $\begin{array}{c}\text { Number of } \\
\text { parasites }\end{array}$ & $\begin{array}{c}\text { Prevalence } \\
\mathbf{9 5 \%} \mathbf{C I}\end{array}$ & $\begin{array}{c}\text { Intensity } \\
\mathbf{( \pm )}\end{array}$ \\
\hline $\begin{array}{c}\text { Ascaridia columbae } \\
\text { (nematode) }\end{array}$ & 16 & $\begin{array}{c}53.3(48.3- \\
54.7)^{\mathrm{b}}\end{array}$ & $3.8 \pm 1.1^{\mathrm{c}}$ \\
\hline Raillitina species (cestode) & 12 & $40(36.6-42.4)^{\mathrm{b}}$ & $0.8 \pm 0.4^{\mathrm{c}}$ \\
\hline Capillaria species (cestode) & 2 & $6.7(3.7-7.7)^{\mathrm{b}}$ & $\begin{array}{c}0.07 \pm \\
0.03^{\mathrm{c}}\end{array}$ \\
\hline $\mathrm{p}=0.061$ & & & \\
\hline
\end{tabular}

The superscript letters $b$ and $c$ indicate insignificant difference of the prevalence between and intensity of the respective parasites.

Table 3: The number of species of intestinal parasite of pigeon encountered at Yan Turaku.

\begin{tabular}{|c|c|c|c|}
\hline Parasite & $\begin{array}{c}\text { Number of } \\
\text { parasites }\end{array}$ & $\begin{array}{c}\text { Prevalence } \\
\mathbf{9 5 \%} \text { CI }\end{array}$ & Intensity ( $\mathbf{\pm})$ \\
\hline Ascaridia columbae & 9 & $56.3(50.8-59.2)^{\mathrm{d}}$ & $2.8 \pm 0.7^{\mathrm{e}}$ \\
\hline Raillitina species & 4 & $25(20.1-29.9)^{\mathrm{d}}$ & $1.0 \pm 0.6^{\mathrm{e}}$ \\
\hline Capillaria species & 3 & $18.7(13.2-23.3)^{\mathrm{d}}$ & $0.09 \pm 0.1^{\mathrm{e}}$ \\
\hline $\mathrm{p}=0.082$ & & & \\
\hline
\end{tabular}

The superscript letters $\mathrm{d}$ and e indicate insignificant difference of the prevalence between and the intensity of the respective parasites.

The prevalence from the study site was low compared to Borji [18], Musa [5], Msoffe [18], Dranzoa [19], Begum and Shaik [8] and Adang [20] and only three species of helminthes endoparasites were encountered. There was no significant difference between the occurrence of the parasites from the two study sites, and there no difference between rates of infection of three parasites encountered [20-22]. This is may be due the fact the sample size was relatively smaller.

\section{Conclusion}

This research study has revealed the presence of gastrointestinal parasites of domestic pigeon in Katsina Township.

Recommendation: A detailed study shall be undertaken to widen the scope of research and also increase the sample size.

\section{Acknowledgement}

We would like acknowledge immeasurable assistance of the teaching and technical staff of the Biology Department, Umaru Musa Yar'adua University, Katsina, the workers and leadership of the Central Abattoir and Yar' Turaku, Katsina, Nigeria.

\section{References}

1. Gmelin (1789) Columba livia Gmelin, 1789 (Web data). ITIS Report.

2. Blechman A (2007) Pigeons-The fascinating saga of the world's most revered and reviled bird. St Lucia, Queensland: University of Queensland Press, Australia.

3. Levi Wendell (1977) The Pigeon. Sumter, SC: Levi Publishing Co, Inc.

4. Marques SM, Quadros RM, Da Silva CJ, Baldo M (2007) Parasites of pigeon (Columba livia) in urban areas of Lages, Southern Brazil. Para Lati 62: 183187.

5. Musa S, Afroz SD, Khanum H (2011) Occurrence of Ecto and Endo Parasites of pigeon (Columba livialinn.). Univ J Zool Rajshahi Univ 30: 73-75.

6. Soulsby EJL (1968) Helminth arthropods and protozoa of domesticated animals. $7^{\text {th }}$ Edn. London, Bailliere Tindall.

7. Anderson RC (2000) Nematode Parasites of Vertebrates: Their Development and Transmission. 2nd Ed. Wallinford, CABI Publishing, Oxon, UK.

8. Begum NJ, Shaikh H (1987) Prevalence of helminth parasites of pigeons (Columba livia). Bang Vet J 21: 89-93.

9. Bennett GF, Peirce MA, Ashford RW (1993) Avian haematozoa: Mortality and pathogenicity. J Nat Hist 27: 993-1001.

10. Urquhart GM (1996) Veterinary Parasitology (1 $1^{\text {st }}$ Ed), ELBS, Longman House, Burnt Mill, Harlow, England, pp. 256-257.

11. Barnek BW, Barnes HJ, Beard CW, McDougald LR, Saif YM (1997) Diseases of Poultry. $10^{\text {th }}$ edn. Ames, IA: Iowa State University Press, USA.

12. Katsina (2018) The Encyclopædia Britannica Online.

13. National Populations Commision, NPC (2006) Population Census: Retrieved $6^{\text {th }}$ July 2018.

14. Katsina (2018) The World Gazetteer.

15. Hendrin CM, Robinson N (2006) Diagnostic Parasitology for Veterinary Technicians ( $3^{\text {rd }}$ Ed.), Mosby Inc. and affiliated of Elesevier Inc. pp. 255260.

16. Cheng TC (1964) The biology of animal parasites. W.B. Sounders company. pp. 654.

17. Ashrafihelan G, Norozi R, Seyed Hosein N, Mehpeikar H (2010) Identification of helminth parasites and gastrointestinal infection domestic pigeon in Tabriz, Iran. Iranian Journal of Veterinary Research 6(3): 52-57.

18. Msoffe PLM, Muhairwa AP, Chiwanga GH, Kassuku AA (2010) A study of ecto and endo parasites of domestic pigeons in Morogoro Municipality, Tanzania. Afri J Agric Res 5(3): 264-267.

19. Dranzoa C, Ocaido M, Katete P (1999) The ecto, gastrointestinal and haemoparasites of live pigeons (Columba livia) in Kampala, Uganda. Path 28(2): 119-124.

20. Adang KL, Oniye SJ, Ajanusi JO, Ezealor AU, Abdu PA (2008) Gastrointestinal helminths of the domestic pigeons (Columba livia domestica Gmelin, 1789 Aves: Columbidae) in Zaria, Northern Nigeria. Sci World J 3(1): 33-37.

21. Yamaguti S (1961) Systema helminthum Vol 3, part 5. In: Nematodes of birds, London, Inter science publishers LTD.

22. Mushi EZ, Binta MG, Chabo RG, Ndebele R, Panjirah R (2000) Parasites of domesticated pigeons (Columba livia domestica) in Sebele, Gaborone, Botswana. J S Afr Vet Assoc 71(4): 249-250. 


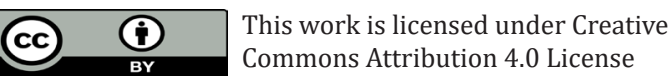

To Submit Your Article Click Here: Submit Article

DOI: 10.32474/CIACR.2019.06.000235

$\begin{gathered}\text { Current Investigations in Agriculture } \\ \text { and Current Research }\end{gathered}$
Assets of Publishing with us
- Global archiving of articles
- Immediate, unrestricted online access
- Rigorous Peer Review Process
- Authors Retain Copyrights
- Unique DOI for all articles

